\title{
Four years of adolescent alcohol-related hospital treatments; trends over time
}

\author{
Joris J van Hoof ${ }^{1}$, Eva van Zanten ${ }^{2}$, Nicolaas van der Lely ${ }^{2 *}$ \\ From International Network on Brief Interventions for Alcohol and Other Drugs (INEBRIA) Meeting 2013 \\ Rome, Italy. 18-20 September 2013
}

\begin{abstract}
Alcohol intoxication among adolescents is an increasing concern in pediatric care. Alcohol use at a young age is related to alcohol abuse in later life. Also, alcohol consumption clusters with other risk seeking behaviors such as substance abuse, high risk sexual engagement, violence and aggression. The WHO recently identified alcohol use amongst young people (10-24 years) as the most important factor contributing to disability adjustable life years (DALYs). To evaluate the trends occurring in the characteristics of adolescents treated for alcohol-related harm in Dutch hospital pediatric departments from 2007 to 2010. From 2007, Dutch pediatricians (NSCK) collected data on adolescents treated for alcohol-related harm. We analyzed all data from 2007 to 2010, involving adolescents suffered from (severe) alcohol intoxication (reduced consciousness). Data was collected via a questionnaire send out to all general and academic Dutch hospitals. Children aged 11-18 years, with a BAC $>0,0 \mathrm{~g} / \mathrm{L}$ and presenting with reduced consciousness were included. A total of 2023 cases were reported in the years 2007-2010 of which 1616 questionnaires were analyzed. Numbers have more than doubled over the years from 297 to 684 reports. Age is increasing among boys (14.9 to 15.6 years, $\mathrm{P}<0.001$ ) but not among girls (14.8 to 15.0 years, $P=0.124)$. Duration of reduced consciousness increased from $2.2 \mathrm{hrs}$ to $3.1 \mathrm{hrs}$ $(\mathrm{P}=0.046)$. Boys are older (15.7 vs. 15.3 years, $\mathrm{P}<0.001)$ and admitted with higher BAC than girls (1.94 vs. 1.79 , $\mathrm{P}=0.001)$. Boys drink more than girls during the weekend (3.34 glasses vs. 1.98 glasses, $\mathrm{P}<0.001$ ). Multivariate analysis shows that $\mathrm{BAC}$ increases with age $(\mathrm{P}=0.042)$, male gender $(P=0.001)$ and higher educational level $(P=0.002)$.
\end{abstract}

\footnotetext{
* Correspondence: lely@rdgg.nl

${ }^{2}$ Department of Pediatrics, Reinier de Graaf Hospital, Delft, the Netherlands

Full list of author information is available at the end of the article
}

\author{
Authors' details \\ 'Behavioral Sciences Faculty, Enschede, the Netherlands. 'Department of \\ Pediatrics, Reinier de Graaf Hospital, Delft, the Netherlands.
}

Published: 4 September 2013

doi:10.1186/1940-0640-8-S1-A33

Cite this article as: van Hoof et al:: Four years of adolescent alcohol-

related hospital treatments; trends over time. Addiction Science \& Clinical Practice 2013 8(Suppl 1):A33.

\author{
Submit your next manuscript to BioMed Central \\ and take full advantage of: \\ - Convenient online submission \\ - Thorough peer review \\ - No space constraints or color figure charges \\ - Immediate publication on acceptance \\ - Inclusion in PubMed, CAS, Scopus and Google Scholar \\ - Research which is freely available for redistribution \\ Submit your manuscript at \\ www.biomedcentral.com/submit
}

C Biomed Central

C 2013 van Hoof et al; licensee BioMed Central Ltd. This is an Open Access article distributed under the terms of the Creative Commons Attribution License (http://creativecommons.org/licenses/by/2.0), which permits unrestricted use, distribution, and reproduction in any medium, provided the original work is properly cited. 